\title{
THE ANALYSIS OF WELFARE AND WORKING SATISFACTION ON THE PRODUCTIVE WORKING BEHAVIOR
}

\author{
Hariyono \\ STKIP PGRI Nganjuk, Indonesia \\ hariyono@stkipnganjuk.ac.id
}

\author{
Ery Tri Djatmika R. W. W. \\ Budi Eko Soetjipto \\ Hari Wahyono
}

State University of Malang, Indonesia

\begin{abstract}
This SMEs in its development has faced numerous problems related to the limitations of workers with high skills (low quality of human resources) and unmotivated employee productive behavior. Unmotivated productive behavior contributes to low employee productivity. Motivating employees to behave productively by providing welfare and working satisfaction to be one of the initiatives in improving performance. Researchers intend to analyze the strategies and capabilities of SMEs in improving human resources and develop a concept of measuring productive work behavior. The purpose of this research is to test antecedents and the mediation of working satisfaction as a contributor to the consequences of employee earning behavior. This study places the welfare variable as an antecedent variable that plays a central role in increasing productive behavior. This research implements survey method. The samples in this study are employees of Ikat bandar weaving consisting of 150 people. This study tested four hypotheses. Research data are nominal and continuum data (interval, ratio and ordinal) as measured by exogenous variable and endogenous variable indicators. Based on SEM (Structural Equation Modeling) from data analysis of LISREL application program, the research findings show that: (1) welfare has a positive effect on work satisfaction; (2) welfare has a positive effect on productive behavior; (3) work satisfaction has a positive effect on productive behavior; and (4) welfare has positive effect on productive behavior through employees' working satisfaction at Ikat Bandar Weaving Center Kediri.
\end{abstract}

Keywords: welfare, working satisfaction, productive behavior

\section{INTRODUCTION}

$\mathrm{HR}$ is considered as a very primary element in a company, therefore every company always strives to have qualified human resources because without a qualified human resources a company will not run properly. Human resources within a company (the world of work) is required to work effectively, efficiently the quality and quantity of good work so that the competitiveness of companies getting bigger [13]. Increasing the effectiveness, efficiency and creativity in an organization depends on the willingness of people in the organization could contribute positively to address change. The demand for the preparation of qualified human resources and high competence will be very urgent and very important [13].

Several factors that affect the behavior of productive work in an organization is the welfare and working satisfaction. These factors are very closely related in improving employee productive working behavior, because with the welfare and working satisfaction of employees will increase employee productivity performance. To increase the productivity of work higher, companies need to generate enthusiasm and excitement of work from employees. In order to support the increase, the company needs to implement the employee welfare program.

Understanding the things that encourage the emergence of productive work behavior, the ability of the managers of the company in terms of creating the factors mentioned above, has a very strong implication to employee productive work behavior. Changes and improvements in the role of human resources functions are essential to support organizational success.

Based on the background and observation at the Ikat Bandar Kidul - Kediri, East Java, there are several problems that need to be studied. Variables to be studied are welfare (X), Working Satisfaction (Z) and productive behavior $(\mathrm{Y})$. The framework of the concept of research is contained in Fig. 1. The conceptual framework of research composed describes the direct influence of welfare variables $(\mathrm{X})$ on working satisfaction $(\mathrm{Z})$ and productive behavior (Y). Each variable has indicators that will be measured from the respondents through the questionnaire.

Based on the research concept framework, four research hypotheses are formulated as follows.

1. Welfare has a significant effect on employee working satisfaction at Ikat Bandar Weaving Center Kediri.

2. Welfare has a significant effect on employee productive behavior at Ikat Bandar Weaving Center Kediri.

3. Working satisfaction has a significant effect on employee productive behavior at Sentra Tenun Ikat Bandar Kediri.

4. Welfare has significant effect on productive behavior through employee working satisfaction at Sentra Tenun Ikat Bandar Kediri.

\section{Research Plan}

\section{METHODS}

This research is conducted by quantitative approach, where in measuring the research variables using survey method and using statistical analysis techniques in processing the measurement data. This research is a survey research, because this research takes sample from one population by using questionnaire as the main data collection tool. In general, which is the unit of analysis in research surveys are individuals [11]. In this study the unit of analysis is employees in the home industry / artisans Ikat Bandar Kidul Artists. 

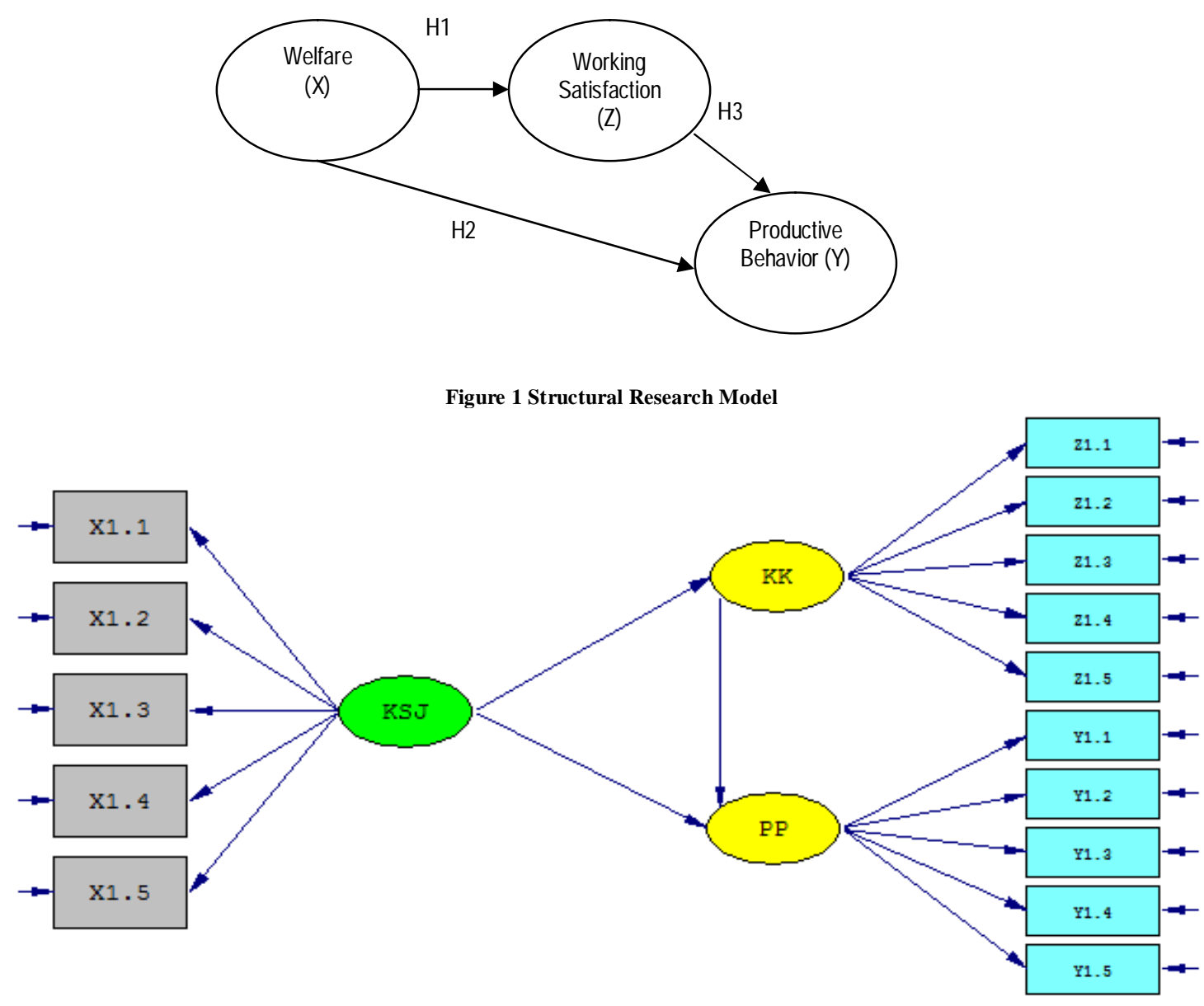

Figure 2 Conceptualization Model of SEM Measurement with Lisrel Notation

The survey research is used for explanatory or confirmatory purposes that is explaining the causal relationship between the variables through hypothesis testing [11]. The data collected are cross sectional data obtained from respondents in answering items related to welfare variables, working satisfaction, and employee productive behavior.

This research is intended to test and analyze the influence of: welfare to working satisfaction, welfare on the productive behavior, welfare on the productive behavior through employee working satisfaction at Ikat Bandar Weaving Center Kediri.

\section{Population and Sample}

Population in this research is all employees who work on 10 artisans Ikat Bandar Kidul weaving Center amounted to 310 people, which was covered as respondents in this research. As employees they gain welfare and working satisfaction at the company.

Distribution of sample based on proportional calculation on 10 (ten) artisans of Ikat Bandar Kidul. Total samples used for employees on the artisans Ikat Bandar Kidul Artists is $=150$ samples, which is determined by simple random sampling technique.

\section{Research Instruments}

Instruments for each of the research variables are developed from indicators of variables whose development is based on the results of theoretical studies, frameworks of thinking and operational definitions that are considered adequate in accordance with the context of this study.

Welfare variable consists of 11 items of questions contained in 5 manifests and using alternative Likert-scale answers. Working satisfaction variable consists of 16 items of questions contained in 5 manifests and using alternative Likert-scale answers. Productive behavior variable consists of 19 items of questions contained in 5 manifests and using alternate five Likert scale answers.

\section{Data Collection Techniques}

Questionnaire technique in this research is used to collect data about welfare, working satisfaction and employee productive behavior. The use of questionnaire technique aims to obtain data from the respondents as research subjects that is about the variables that will be measured, including: welfare, working satisfaction and employee productive behavior. This questionnaire, contains questions by giving score (value) of each answer that is by using Likert scale. Score of the respondent's answer is given with five alternative choices that is, strongly agree (SS) with score 5, agree (SJ) with score 4, neutral (N) with score 3, disagree (TS) with score 2, Disagree (STJ) with a score of 1 . The measurement level used is ordinal, where the numbers given contain level understanding. The distribution of questionnaires is done by visiting respondents directly and coordinating with related agencies and craftsmen / entrepreneurs weaving bands. In this case the study was conducted in April 2017. 


\section{Data Analysis}

Data analysis technique used in this research is Structural Equation Modeling (SEM). SEM software used in this research is Linear Structural Relationships (LISREL) version 8.80. Prior to data analysis using structural equation modeling, it is necessary to test the unidimensionality of the constructs on each of the variables studied. The analysis is done by using confirmatory factor analysis.

\section{RESULT}

\section{Research Conceptual Test Model}

The results of the initial model test as the conceptual model in this study is shown in figure 1 as follows. It appears in the figure above that the conceptual model does not yet have a degree of conformity that meets the requirements according to the criteria requirements of a structural equation model. In addition to the lambda coefficient or factor loading of each manifest construct valid, the coefficient of structural equation that describes the level of influence of exogenous variables on the endogenous variables is also significant. Nevertheless, model Conformity should also be seen from the adequacy of the determinants of the degree of Conformity in meeting the criteria in accordance with the requirements of the structural model analysis. This can be seen in the following Table 1 .

Table 1 above shows that there are many unmet Conformity model requirements. Based on this it can be stated that the conceptual model as proposed and hypothesized and presented in the conceptual model of empirical research has not yet met the requirements of the conformity model test.

\section{Result of Model Test Simulation Analysis}

From three rounds the simulation of the measurement model performed directly has a goodness of fit with a coefficient of magnitude that meets the criteria as an empirical model of good research findings.

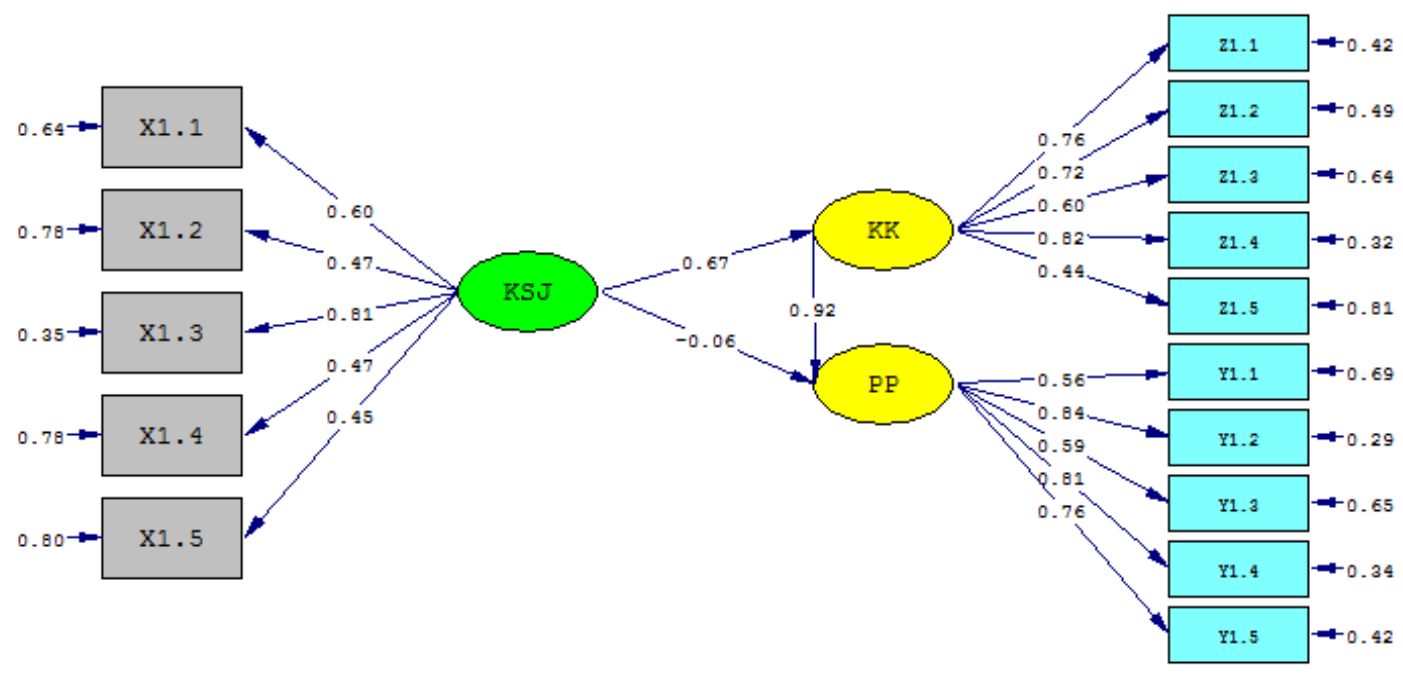

Chi-9quare $=332.10, d f=87, p-v a l u e=0.00000$, RMSEA $=0.138$

Figure 3 Research Conceptual Model (Initial Model)

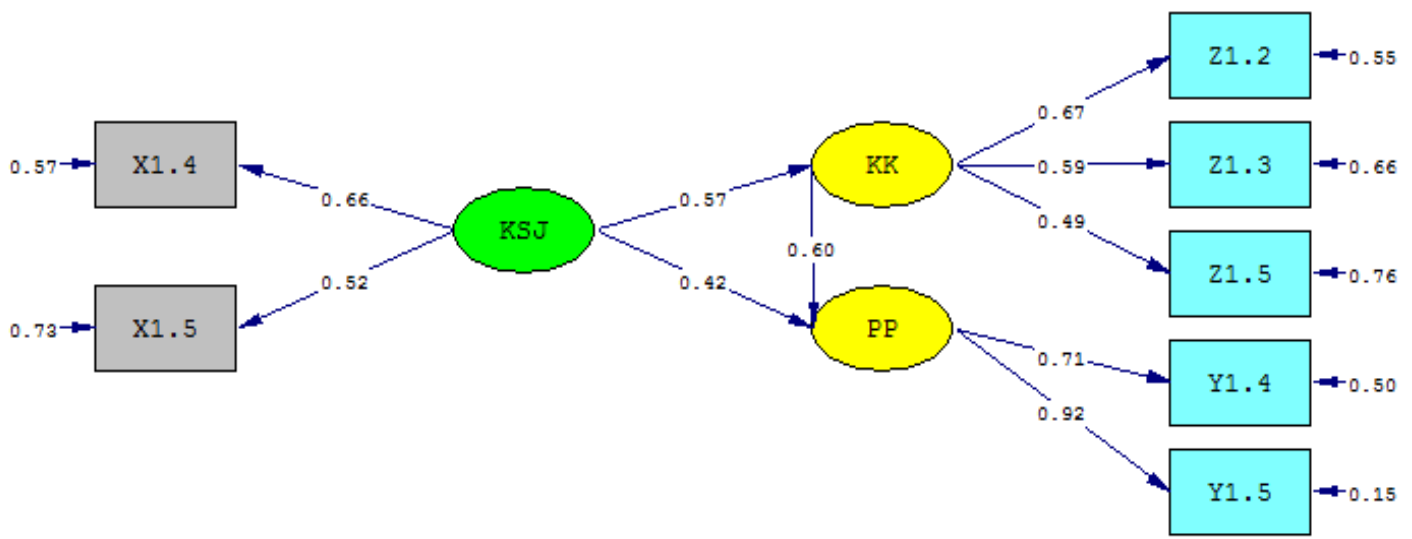

Chi-Square $=15.49, d f=11, \mathrm{P}-\mathrm{value}=0.16129, \mathrm{RMSEA}=0.052$

Figure 4 Alternative Model 
Table 1

Conformity of Research Conceptual Model (Initial Model)

\begin{tabular}{cccc}
\hline Conformity of the Model & Coefficient & Criteria & Conclusion \\
\hline Chi-square $\left(\chi^{2}\right)$ & 332.10 & Big / Significan & Fulfilled \\
P-Volue & 0.000 & $\geq 0.05$ & Not Fulfilled \\
Df & 87 & --- & -- \\
Cmin $\left(\chi^{2} / \mathrm{Df}\right)$ & 3.8172 & $\leq 2.00$ & Not Fulfilled \\
RMR (Standadised) & 0.091 & $\leq 0.08$ & Not Fulfilled \\
RMSEA & 0.138 & $\leq 0.08$ & Not Fulfilled \\
GFI & 0.77 & $\geq 0.90$ & Not Fulfilled \\
AGFI & 0.68 & $\geq 0.90$ & Not Fulfilled \\
CFI & 0.86 & $\geq 0.94$ & Marginal \\
IFI & 0.86 & $\geq 0.94$ & Marginal \\
NNFI & 0,83 & $\geq 0.94$ & Marginal \\
AIC / Model & 398.10 & Small / Relative & Fulfilled \\
\hline
\end{tabular}

(Source: Output Lisrel on the Initial Research Model, 2017)

Table 2

Conformity of Structural Research Model (Alternative Model)

\begin{tabular}{cccc}
\hline Conformity Model & Coefficient & Criteria & Conclusion \\
\hline Chi-square $\left(\chi^{2}\right)$ & 15.49 & Besar (signifikan) & Fulfilled \\
P-Volue & 0.16129 & $\geq 0.05$ & Fulfilled \\
Df & 11 & -- & -- \\
Cmin $\left(\chi^{2} / \mathrm{Df}\right)$ & 1.41 & $\leq 2.00$ & Fulfilled \\
RMR (Standadised) & 0.04 & $\leq 0.08$ & Fulfilled \\
RMSEA & 0.052 & $\leq 0.08$ & Fulfilled \\
GFI & 0.97 & $\geq 0.90$ & Fulfilled \\
AGFI & 0,95 & $\geq 0.90$ & Fulfilled \\
CFI & 0.99 & $\geq 0.94$ & Fulfilled \\
IFI & 0.99 & $\geq 0.94$ & Fulfilled \\
NNFI & 0.97 & $\geq 0.94$ & Fulfilled \\
AIC / Model & 49.49 & Kecil / Relatif & Fulfilled \\
\hline
\end{tabular}

(Source: Output Lisrel of Alternative Research Model , 2017)

Table 3

Comparison of Conformity Coefficient from both Models

\begin{tabular}{ccc}
\hline Conformity Model & Initial Model & Alternative Model \\
\hline Chi-square $\left(\chi^{2}\right)$ & 332.10 & 15.49 \\
P-Volue & 0.000 & 0.16129 \\
Df & 87 & 11 \\
Cmin $\left(\chi^{2} /\right.$ Df $)$ & 3.8172 & 1.41 \\
PMR (Standardised) & 0.091 & 0.04 \\
RMSEA & 0.138 & 0.052 \\
GFI & 0.77 & 0.97 \\
AGFI & 0.68 & 0.95 \\
CFI & 0.86 & 0.99 \\
IFI & 0.86 & 0.99 \\
NNFI & 0.83 & 0.97 \\
AIC / Model & 398,10 & 49.49 \\
\hline
\end{tabular}

It appears in the figure above that the alternative model already has a level of conformity that meets the requirements in accordance with the criteria requirements of a structural equation model. In addition to the lambda coefficient or factor loading of each manifest construct valid, the coefficient of structural equation that describes the level of influence of exogenous variables on the endogenous variables is also significant. Nevertheless, conformity model should also be seen from the adequacy of the determinants of the degree of conformity in meeting the criteria in accordance with the requirements of the structural model analysis. This can be seen in the following table.
Table 2 above shows that it proves to have met the best Conformity requirements, and is a structural model that empirically corresponds to the phenomena occurring in the research background. Thus hypothesis testing, discussion and conclusion will be based on this alternative model which proved to be the best model of the findings in this study.

\section{Hypothesis Testing}

Table 4

Hypothesis Testing

\begin{tabular}{|c|c|c|c|}
\hline No & Hypothesis & Result & Conclusion \\
\hline 1. & $\begin{array}{l}\text { Welfare has a positive effect on employee working } \\
\text { satisfaction at Ikat Bandar Weaving Center Kediri. }\end{array}$ & $\begin{array}{l}\text { Based on the result of LISREL analysis } 8.80 \text { on } t \text {-value } \geq t \text { table, that is } \\
3.91 \geq 1,97 \text { or } 2 \text { then } \mathrm{H} 0 \text { is rejected and } \mathrm{H} 1 \text { is accepted. }\end{array}$ & Proven \\
\hline 2. & $\begin{array}{l}\text { Welfare has a positive effect on employee productive } \\
\text { behavior at Ikat Bandar Weaving Center Kediri }\end{array}$ & $\begin{array}{l}\text { Based on the result of LISREL analysis } 8.80 \text { on t-value } \geq \mathrm{t} \text { table, that is } \\
2.88 \geq 1,97 \text { atau } 2 \text { so } \mathrm{H} 0 \text { is rejected and } \mathrm{H} 1 \text { is accepted }\end{array}$ & Proven \\
\hline 3. & $\begin{array}{l}\text { Working satisfaction has a positive effect on employee } \\
\text { productive behavior at Ikat Bandar Weaving Center } \\
\text { Kediri }\end{array}$ & 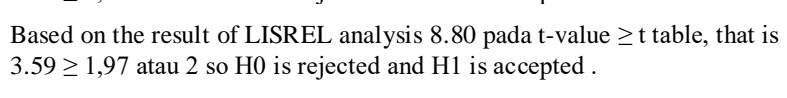 & Proven \\
\hline 4. & $\begin{array}{l}\text { Welfare has a positive effect on employee productive } \\
\text { behavior through working satisfaction at Ikat Bandar } \\
\text { Weaving Center Kediri }\end{array}$ & $\begin{array}{l}\text { Based on the result of LISREL analysis } 8.80 \text { on } t \text {-value } \geq t \text { table, that is } \\
3.75 \geq 1,97 \text { or } 2 \text { so } \mathrm{H} 0 \text { is rejected and } \mathrm{H} 1 \text { is accepted }\end{array}$ & Proven \\
\hline
\end{tabular}




\section{DISCUSSION}

The Effect of Welfare on Employee Working Satisfaction at Ikat Bandar Weaving Center Kediri

Based on the results of research on employees of Ikat Bandar weaving concluded that hypothesis 1 which states that welfare has an effect on employee work satisfaction Ikat Bandar weaving is accepted, it is shown from the value coefficient on t-value 3.91 compared with the table value is 1.97 is bigger. The value indicates that the better welfare by employees, the better the employee's working satisfaction will be. Conversely, if the welfare of employees is not good, it will make employee working satisfaction becomes low.

Working satisfaction is a (positive) attitude of the workforce, based on the assessment of the work situation can be done on one of his work, the assessment is done as a sense of appreciation in achieving one of the important values in the work.

This study shows that employee perspective in welfare with indicators of salary or wages, health services, bonuses and intensive, old age insurance and protection as reflective of welfare can affect working satisfaction enhancement that is reflective with work, rewards of work, loving work, improving work performance and relationships in work.

This research has impacted on the welfare of employees at the center of Ikat Bandar Sub district Mojoroto Kediri more advanced in the pattern of thinking to be more creative and innovative. Employees take careful consideration in spending their income, employees tend to pay attention in spending their money really usefully.

The Effect of Welfare on Employee Productive Behavior at Ikat Bandar Weaving Center Kediri

Based on the results of SEM hypothesis testing resulted that the answer that hypothesis 2 which states that welfare has a significant influence on productive behavior of employees Ikat Bandar weaving is accepted, it is shown from the value of coefficient on tvalue 2.88 and compared with the value of $t$ table that is 1, 97 is larger. The value indicates that the better welfare by employees, the better the productive behavior of employees. Conversely, if the welfare of employees is less / not good, it will make the productive behavior becomes low.

This research supports the research by [12] that Welfare has a positive and significant influence on the performance of employees in Dinoh Education Office Sukoharjo, meaning that the higher the welfare of the employee performance will be higher. Higher rewards will attract and retain employees so as to spur the increase in work productivity. And support Dhermawan's research [1], that the variable of compensation to the performance variable shows a positive and significant influence, this means that the increase of compensation will give impact to the employee performance and vice versa if the compensation given to the employee is not good.

Based on the indicators in this study, the higher welfare is reflected in the increasing work calmness, loyalty, attachment to the organization, motivation of passion, maintaining health and physical quality of employees, creating a better environment and working atmosphere, and spurring work productivity.

The Effect of Working satisfaction on Employee Productive Behavior at Ikat Bandar Weaving Center Kediri

Based on the results of research on employees of Ikat Bandar Weaving Center concluded that the hypothesis 3 which states that working satisfaction has a significant influence on productive behavior of employees of Band Ikat received, this is shown from the coefficient value at t-value 3.59 and compared with the table value is 1.97 Is bigger. The value indicates that the better working satisfaction received by employees, the better the productive behavior of the employee. Conversely, if the employee satisfaction is less / not good, it will make the productive behavior becomes low. This research supports the research of [7], where working satisfaction has a positive and significant effect on work productivity of employees. This research supports research [14], [7] and [5].

Furthermore, according to the results of Dhermawan research [1], that there is a positive and significant influence between working satisfaction variables to performance variables, this means that if the working satisfaction of employees in the Social Work Office of Bali Province is good, it will increase the performance of its employees. Conversely, if working satisfaction perceived employee less / not good, hence will performance of employees will be low, so the better working satisfaction perceived by employee, hence will be better also performance of employee.

This is in accordance with the theory that states working satisfaction as an attitude that describes how a person feels about his work as a whole and to various aspects of his work. This shows that working satisfaction is how much a person likes or dislikes his work and is closely related to various aspects of his work such as salary and bonus receipts, work itself, coworkers, promotions and work environments. That working satisfaction is an important factor, because working satisfaction will have an impact on someone's work productivity.

\section{The Effect of Welfare on Productive Behavior through Employee Working satisfaction at Ikat Bandar Weaving Center Kediri}

Based on the results of research on employees of Ikat Bandar Weaving Center concluded that the hypothesis 4 which states that the welfare has a significant influence on productive behavior through working satisfaction employee of Ikat Bandar Weaving Center is accepted, it is shown from the value coefficient on t-value 3.75 and compared with the table that is 1.97 is bigger. The value indicates that the better the work welfare and the satisfaction received by the employee, the better the productive behavior of the employee. Conversely if the welfare and employee satisfaction is less / not good, it will make productive behavior becomes low. This research supports the research of Kusumawati (2013), where the giving of 
the significant effect to the employee performance of RSUD dr. Moewardi in Surakarta.

It also supports the opinion of Flippo (2002) contains the following statement a compensation plan variable (in this case the employee welfare services program) is designed for encourage individuals and groups, certain types of behavior deemed to improve organizational effectiveness [2]. From the opinion is clearly seen that the company seeks to improve the effectiveness of the company through the provision of variable compensation, one of which is employee welfare services. Due to the increased welfare of employees will generate employee enthusiasm and passion that automatically indirectly will increase the productivity of the employees themselves.

\section{CONCLUSION}

The result of analysis shows that there is a positive effect of welfare on working satisfaction as shown by t-value 3,91. It indicates that the welfare possessed by the employees affects the employee's working satisfaction. The value of t-value 2.88 is obtained when testing the influence of welfare on productive behavior, this result indicates that there is significant influence from welfare variable to productive behavioral variable, this result shows that employee's well-being improves hence increasing employee productive behavior.

At the value of t-value 3.59 obtained from the analyst's results to test the effect of working satisfaction on productive behavior, showing the hypothesis stating that working satisfaction has a significant effect on productive behavior, accepted. This means that the better the level of working satisfaction of employees, it will be increasing also productive behavior by employees. As well for t-value 3.75 obtained from the analysis to test the hypothesis about the effect of welfare on productive behavior through working satisfaction, this shows high t-value compared with t-table 1.97.

This means that the better the welfare of employees, it will increase productive behavior, it's just supported by an increase in employee working satisfaction at Ikat Bandar Weaving Center Kediri. This is in accordance with the targeted findings of new constructs on Employee Productive Behavior Causality, through welfare factors against employee productive behavior and indirect influence through employee working satisfaction. Suggestion This research has a fundamental contribution that is the development of science in the field of organizational behavior and have the leading for the organization of SMEs Kediri, especially in decision-making and improvement of employee performance.

Therefore, coaching conducted on SMEs more oriented improvement of competent human resources in managing SMEs, enhancement of skilled entrepreneur-oriented SMEs to empower SMEs to be more creative, innovative and labor intensive. Increasing the professionalism of human resources to overcome the basic problems of SMEs with the measurement of productive work behavior through working satisfaction and employee welfare level so that the need for coaching activities to attract interest and encourage employees to be more productive behavior.

\section{REFERENCES}

[1] Dhermawan, A. N. B., Sudibya, I. G. A., Utama, I. M. 2012. Pengaruh Motivasi, Lingkungan Kerja, Kompetensi, dan Kompensasi terhadap Kepuasan Kerja dan Kinerja Pegawai di Lingkungan Kantor Dinas Pekerjaan Umum Provinsi Bali. Jurnal Manajemen, Strategi Bisnis, dan Kewirausahaan, Vol. 6, No. 2 Agustus 2012.

[2] Gondokusumo, S., and Eddy M. S. 2015. Motivasi Kerja, Kepuasan Kerja, dan Komitmen Organisasional Karyawan. JMK, Vol. 17, No. 2, September 2015, 186196

[3] Hasibuan, M. S. P. 2016. Manajemen Sumber Daya Manusia. Jakarta: Bumi Aksara.

[4] Indy, H., and Seger, H. 2013. Hubungan Kepuasan Kerja dengan Motivasi Kerja pada Karyawan Bank BTPN Madiun. Jurnal Psikologi Industri dan Organisasi, Vol. 2 No. 2 Agustus 2013. Fakultas Psikologi Universitas Airlangga.

[5] Koesmono, H. T. 2006. Pengaruh Budaya Organisasi terhadap Motivasi dan Kepuasan Kerja serta Kinerja Karyawan pada Subsektor Industri Pengolahan Kayu Skala Menengah di Jawa Timur. Jurnal Manajemen dan Kewirausahaan (Journal of Management and Entrepreneurship), 7(2), pp. 171-188.

[6] Laniwidyanti. 2010. Pengaruh Hubungan Kerja, Pengalaman Kerja Dan Motivasi Kerja Terhadap Kinerja Karyawan Bank Central Asia (BCA) Cabang Borobudur, Malang. Wacana Vol. 13 No.2. April 2010 ISSN. 1411-0199.

[7] Prasetyo, E., \& Wahyuddin, M. 2003. Pengaruh Kepuasan dan Motivasi Kerja terhadap Produktivitas Kerja Karyawan Riyadi Palace Hotel di Surakarta. Retrieved April, 2, 2016.

[8] Robbins, S. P. \& Timotya A. J.. 2015. Organizational Behavior. Jakarta: Salemba Empat.

[9] Siagian, S.P. 2009. Kiat Meningkatkan Produktivitas Kerja. Jakarta: Rineka Cipta.

[10] Simanjuntak, M. 2010. Peningkatan Perilaku Profesionalisme Pekerja Menghadapi Tantangan Globalisasi Pada Abad 21. Binus Business Review, Vol. 1 No. 2 November 2010: 319-331.

[11] Singarimbun, M., \& Effendi, S. 1995. Metode Penelitian Survei. Jakarta: LP3ES.

[12] Sriwidodo, U., \& Budhi, H. 2010. Pengaruh Kompetensi, Motivasi, Komunikasi dan Kesejahteraan terhadap Kinerja Pegawai Dinas Pendidikan. Jurnal Manajemen Sumber Daya Manusia.

[13] Suhariadi, F. 2013. Manajemen Sumber Daya Manusia dalam Pendekatan Teoritis Praktis. Surabaya: Airlangga University Press.

[14] Widodo, F.A.S., \& Sami'an, M. 2013. Hubungan Employee Engagement dengan Perilaku Produktif Karyawan. Jurnal Psikologi Industri dan Organisasi, 2 (1).

[15] Zurnali, C. 2011 Pengaruh Pelatihan dan Motivasi terhadap Perilaku Produktif Karyawan di Divisi Long Distance PT Telkom, Tbk. Indonesia. Jurnal Kajian Ekonomi dan Bisnis Oikos-Nomos. Volume 4. No. 1. Januari 2011. 